\title{
TATA LETAK ILUSTRASI DITINJAU DARI SEGI PROPORSIONAL ILUSTRASI PADA BUKU PENDAMPING TEMATIK TERPADU IPA JILID 1 SESUAI KURIKULUM 2013 TERBITAN ERLANGGA
}

\author{
Aulia Dwiningtyas Putri, Irene Maria Juli Astuti \\ Program Studi Penerbitan, Jurusan Penerbitan, \\ Politeknik Negeri Media Kreatif Jakarta
}

\begin{abstract}
:
This research aims to describe the problem in the book layout related 2013 curriculum illustration that proportionate in terms of illustration. This research focuses on the Integrated Thematic Companion Book Vol. 1 IPA. The research method used is the method of library research, observation, and interviews. The results can be concluded that the main obstacle is the difficulty of inserting an illustration into the box the picture proportionally. The fix is to change the size/shape of the illustration through the program Adobe Illustrator or by changing the size of the picture box on the form/Adobe InDesign.
\end{abstract}

Keywords: layout, illustration, proportional illustrastion

\section{PENDAHULUAN}

Seni gambar ilustrasi dari zaman ke zaman terus mengalami perkembangan. Seiring dengan berkembangnya teknologi komputer, kini ilustrasi dapat dibuat dengan beberapa program, seperti Adobe Ilustrator, Adobe Photoshop, dan Adobe CorelDraw. Keberadaan program ini dapat mempermudah proses pengerjaannya, seperti memodifikasi, membuat ilustrasi yang baru dan dapat menggandakan ilustrasi dengan cepat. Ilustrasi tersebut digunakan untuk menambah penjelasan dari suatu cerita atau sebagai pendukung cerita. Ilustrasi yang disajikan haruslah sesuai dengan isi atau kebutuhan buku tersebut. Ilustrasi harus menarik perhatian konsumen agar membeli dan membaca buku tersebut.

Menurut Adi Kusrianto dalam bukunya Pengantar Desain Komunikasi Visual (2007) dijelaskan ilustrasi yaitu seni gambar yang dimanfaatkan untuk memberi penjelasan atas suatu maksud atau tujuan secara visual. Dapat disimpulkan ilustrasi adalah gambar untuk memberi penjelasan dari isi naskah atau sebagai pendukung cerita. Ilustrasi juga terdapat pada buku-buku pelajaran sekolah dasar seperti pada Buku Pendamping Tematik Terpadu IPA Jilid 1. Buku tersebut termasuk dalam buku latihan untuk siswa kelas satu sekolah dasar yaitu sebagai buku pendamping terbitan Erlangga yang di dalamnya banyak terdapat ilustrasi. 
Berdasarkan Kamus Besar Bahasa Indonesia (2008:1409), tata unsur grafika pada halaman atau seluruh barang cetakan supaya yang disajikan kelihatan menarik dan mudah dibaca. Pengaturan tata letak pada sebuah buku sangat penting dilakukan pada setiap penerbit buku terutama pada buku-buku sekolah. Buku-buku sekolah diatur tata letak elemen-elemen didalamnya sedemikian menarik tujuannya agar siswa tertarik untuk membaca dan mempelajarinya.

Rumusan masalah utama yang dikaji yaitu apa kendala yang ada selama proses pengaturan tata letak ilustrasi ditinjau dari segi proporsional ilustrasi pada $B u k u$ Pendamping Tematik Terpadu IPA Jilid 1 dan cara mengatasinya sesuai penelitian yang dilakukan penulis selama praktik industri di penerbit Erlangga? Dari perumusan masalah yang telah dihimpun maka tujuan penulisan ini adalah untuk mengetahui apa kendala yang dialami selama proses tata letak ilustrasi ditinjau dari segi proporsional ilustrasi pada $B u k u$ Pendamping Tematik Terpadu IPA Jilid 1 dan cara mengatasinya.

Pada tahun 1938-1946, Laszlo Moholy-Nagy membuka Institut Desain pertama di Amerika dengan kurikulum desain modern. Kesadaran akan pentingnya kurikulum desain di universitas dan sekolah-sekolah seni mulai bangkit di tahun 50-an. Grid sebagai alat bantu untuk tata letak mulai terkenal sejak hadirnya karyakarya Josef Muller-Brockmann dan letak adalah pengaturan,
penempatan, dan penataan Richard Paul Lohse di Swiss. Desain majalah mulai marak di tahun 1960an. Tahun 1990-an perkembangan media digital sangat pesat. Sama halnya dengan perkembangan program-program pendukung pembuatan tata letak seperti Adobe Indesign, Quark Ekspress, PageMaker, dan lain-lain.

Sejak merebaknya teknologi internet dan nirkabel, banyak asumsi yang mengatakan era kematian media cetak dimulai. Namun pada kenyataannya hingga kini asumsi tersebut tidak terbuki. Ada beberapa hal yang tidak dapat menggantikan posisi media cetak, antara lain informasi yang tercetak di atas kertas adalah dokumen yang lebih dapat diandalkan dan dipercaya keabsahannya. Contohnya dokumendokumen yang menyangkut masalah legalitas, sertifikat, perjanjian. Selain itu, karena berupa benda fisik yang dapat dirasakan lewat panca indera, kita dapat memasukkan unsure realuser-experience melalui tekstur, aroma/bau atau ukuran yang tidak terbatas yang tidak dapat dilakukan oleh media digital.

Menurut Prof. Mudrajad Kuncoro, Ph.D. dalam bukunya Mahir Menulis (2009:132) dijelaskan layout merupakan penanganan tata letak dan penampilan fisik penerbitan secara umum. Tata letak teks dilakukan untuk mengatur elemen teks pada naskah agar nantinya memudahkan pembaca untuk memahami isinya dan terlihat lebih 
rapi pada setiap halaman. Tata letak dilakukan tidak hanya pada teks antara teks dan ilustrasi haruslah memiliki keseimbangan. Jika dilihat dari proses tata letak teks dan ilustrasi, proses tersebut merupakan salah satu langkah dari tersusunnya rancangan suatu buku.

Saat ini, sudah banyak program-program page layout yang telah dikenal oleh masyarakat, salah satu contohnya adalah Adobe InDesign. Program ini dapat memudahkan dalam mengatur tata letak dalam jumlah halaman yang banyak. Penggunaan garis-garis (atau titik-titik) maya yang tidak akan tercetak saat gambar dicetak akan membantu desainer saat mengatur tata letak objek di bidang cetak garap. Selain itu, grid juga berfungsi untuk menjaga keproporsionalan tata letak. Dalam Buku Pendamping Tematik Terpadu IPA Jilid 1 penggunaan grid juga untuk menjaga keproporsionalan pengaturan box gambar. Hal ini dilakukan agar peletakan box gambar pada buku tersebut lebih rapi dan mudah dimengerti oleh siswa.

Surianto Rustan dalam bukunya Layout Dasar dan Penerapannya (2008:23) mengatakan bahwa tujuan berbagai elemen dalam suatu tata letak adalah menyampaikan informasi dengan lengkap dan tepat, yang kedua: kenyamanan dalam membaca termasuk di dalamnya. Elemen tata letak dibagi menjadi tiga, yaitu elemen teks, elemen visual (gambar), dam invisible element. Menurut melainkan juga pada ilustrasi. pengaturan tata letak Kamus Besar Bahasa Indonesia (2008:526) ilustrasi adalah (1) gambar (foto, lukisan) untuk membantu memperjelas isi buku, karangan, dsb; (2) gambar, desain, atau diagram untuk penghias (halaman sampul dsb); (3) (penjelasan) tambahan berupa contoh, bandingan, dsb untuk lebih memperjelas paparan (tulisan dsb)".

Anatomi buku berarti membahas mengenai segi fisik suatu buku. Buku terdiri dari beberapa bagian didalamnya, salah satu contohnya terdiri dari cover, pendahulu, dan lain-lain. Setiap buku berbeda-beda anatomi-nya karena beda jenisnya. Misalnya, anatomi novel berbeda dengan anatomi buku pelajaran. Yang sama dari anatomi buku yaitu memiliki cover dan isi. Dalam artikel mengenal anatomi buku menurut Putra bagian buku yang lengkap terdiri dari beberapa bagian, yaitu sampul depan (cover), pendahulu (preliminaries), isi (text matter) dan penyudah (postliminaries).

Tata letak berarti aturan meletakkan elemen-elemen yang terdapat pada naskah agar terlihat lebih rapi. Pengaturan tata letak juga dilakukan pada naskah buku pelajaran. Tata letak buku pelajaran harus dirancang sedemikian rupa sehingga agar siswa tidak kesulitan pada saat mempelajarinya. Perencanaan awal dilakukan dengan membuatkan templet atau gambaran buku yang akan dicetak. Templet 
atau gambaran dapat dibuat dengan software Adobe Indesign atau dibuat penempatannya harus diatur, seperti tempat judul, subjudul, nomor halaman, dan judul berjalan.

Pengaturan tata letak juga dilakukan pada sebuah ilustrasi. Tata letak ilustrasi juga sangat mempengaruhi isi buku yang akan dicetak nantinya. Tidak hanya itu, tata letak ilustrasi juga harus diletakkan berdekatan dengan teks agar tidak membinggungkan pembaca, terutama pada buku pelajaran. Pada buku pelajaran ilustrasi memiliki fungsi penting agar informasi yang disampaikan pada buku pelajaran dapat cepat dimengerti oleh siswa dengan bantuan ilustrasi.

Adi Kusrianto dalam bukunya Pengantar Desain Komunikasi Visual (2007:157) menjelaskan ilustrasi berwarna yang terutama dibuat dengan pena dan tinta hitam maupun cat air, kini digantikan dengan program-program gambar berbasis vektor seperti Ilustrator, Coreldraw, canvas, maupun FreeHand. Kemudahan gambar yang diperoleh menggunakan komputer dapat dimodifikasi dan digandakan dengan cepat, baik secara keseluruhan maupun di bagianbagian tertentu sehingga pembuatan efek-efek yang sama pada saat harus membuat adegan lain dari ilustrasi akan menjadi lebih mudah.

Menurut Prof. Dr. B.P. Sitepu, M.A dalam bukunya Penulisan Buku Teks Pelajaran (2012:151) dijabarkan fungsi-fungsi ilustrasi pada lembaran-lembaran kertas kosong. Bagian-bagian yang sebagai berikut : a) menarik perhatian pembaca; b) membuat konsep lebih konkret; c) menghindarkan istilah-istilah teknis; d) Menjelaskan konsep visual; e) Menjelaskan konsep spasial; f) Menimbulkan minat dan motivasi; g) membantu siswa yang lambat membaca; h) membantu mengingat lebih lama.

\section{METODE PENELITIAN}

Metode yang digunakan adalah metode studi kepustakaan, observasi, dan wawancara. Penulisan ini tentunya untuk memberikan bayangan mengenai tata letak ilustrasi yang ditinjau dari segi proporsional ilustrasi pada Buku Pendamping Tematik Terpadu IPA Jilid 1 terbitan Erlangga. Metode ini untuk mengumpulkan data-data demi kelengkapan penulisan Tugas Akhir dengan cara sebagai berikut.

1. Kepustakaan

Metode ini dilakukan dengan mencari data-data referensi, seperti buku, artikel, dan tugas akhir terkait pada pembahasan pada penulisan Tugas Akhir ini. Metode studi kepustakaan dilakukan di Perpustakaan Nasional, Perpustakaan Politeknik Negeri Media Kreatif, dan Perpustakaan Universitas Indonesia.

2. Observasi

Metode ini dilakukan dengan mengamati kegiatan-kegiatan di penerbit Erlangga terkait pada 
tata letak ilustrasi dari segi proporsional ilustrasi dalam penulisan Tugas Akhir ini. Penulis mengamati bagaimana mengatur tata letak ilustrasi dari segi proporsional ilustrasi dan mengamati ilustrasi pada bukubuku pendamping tematik terpadu dalam lingkup editorial buku pelajaran.

3. Wawancara

Metode ini dilakukan dengan cara mencari data-data akurat dari narasumber di penerbit

\section{HASIL DAN PEMBAHASAN}

\section{Pola Tata Letak Ilustrasi}

Grid berfungsi sebagai alat bantu dalam mengatur tata letak elemen-elemen di dalam naskah. Pada Buku Pendamping Tematik Terpadu IPA Jilid 1 ini, grid digunakan untuk mengatur elemenelemen visual. Tujuan menggunakan grid agar tata letak ilustasi dapat sejajar dan terlihat teratur antara ilustrasi yang satu dengan yang lain Erlangga.

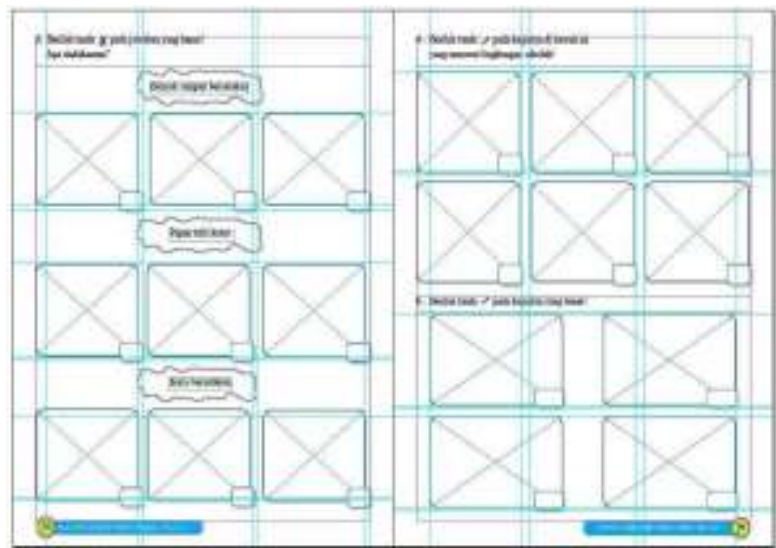

Gambar 1 Contoh halaman Buku Pendamping Tematik Terpadu IPA Jilid 1 box gambar yang menggunakan Grid pada Program Adobe Indesign
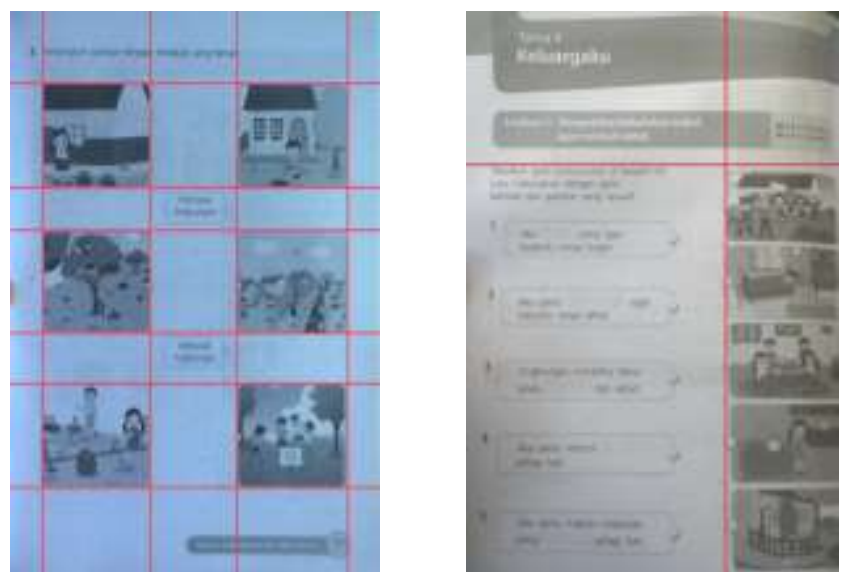

Gambar 2 lembar naskah ilustrasi yang menggunakan grid 


\section{Segi Fisik Buku}

Berdasarkan Buku Pintar Penyuntingan Naskah (2009:144) segi fisik suatu buku yang dijadikan penilaian dasar terdiri dari beberapa bagian penting. Beberapa diantaranya yaitu jenis kertas, ukuran buku, jumlah halaman, dan penggunaan warna. Maka pada Buku Pendamping Tematik Terpadu IPA Jilid 1 ini terdiri dari :

1. Pada Buku Pendamping Tematik Terpadu IPA Jilid 1 ini, jenis kertas yang digunakan pada cover adalah Art Carton 230 gram. Sedangkan untuk halaman ini menggunakan kertas HVS 70 gram.
2. Pada Buku Pendamping Tematik Terpadu IPA Jilid 1 ini, ukuran buku nya adalah $21 \times 26 \mathrm{~cm}$ dengan berat 276 gram. Ukuran buku ini digunakan juga pada buku pendamping tematik terpadu mata pelajaran lainnya. Ukuran buku 29 sangat sesuai jika dilihat dari sasaran pembacanya yaitu siswa sekolah dasar kelas 1.

3. Untuk Buku Pendamping Tematik Terpadu IPA Jilid 1 ini menggunakan katern kelipatan 8 . (4) Buku Pendamping Tematik Terpadu IPA Jilid 1 untuk bagian cover full colour sedangkan untuk bagian isi menggunakan warna hitam putih atau blackwhite.

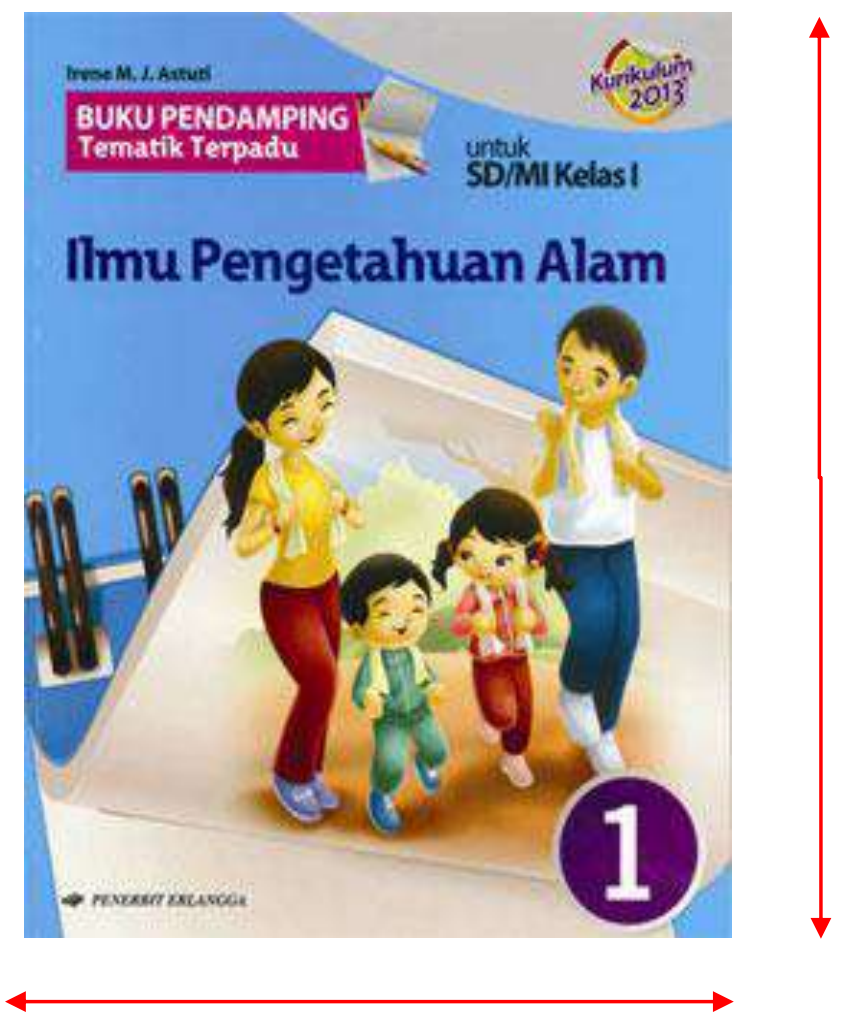

Gambar 3 Cover Buku Pendamping Tematik Terpadu IPA Jilid 1 


\section{Desain Cover}

Elemen Tata Letak Pada
Cover merupakan daya tarik tersendiri dari buku tersebut. Apabila cover menarik maka orang akan penasaran terhadap buku tersebut. Sama halnya pada Buku Pendamping Tematik Terpadu IPA Jilid 1 ini, cover diolah sedemikian bagus agar siswa tertarik untuk melihat buku tersebut. Pada cover terdapat nama penulis, judul buku, jenjang kelas, logo penerbit, dan ilustrasi yang menggambarkan isi buku. Elemen teks pada cover adalah judul dan

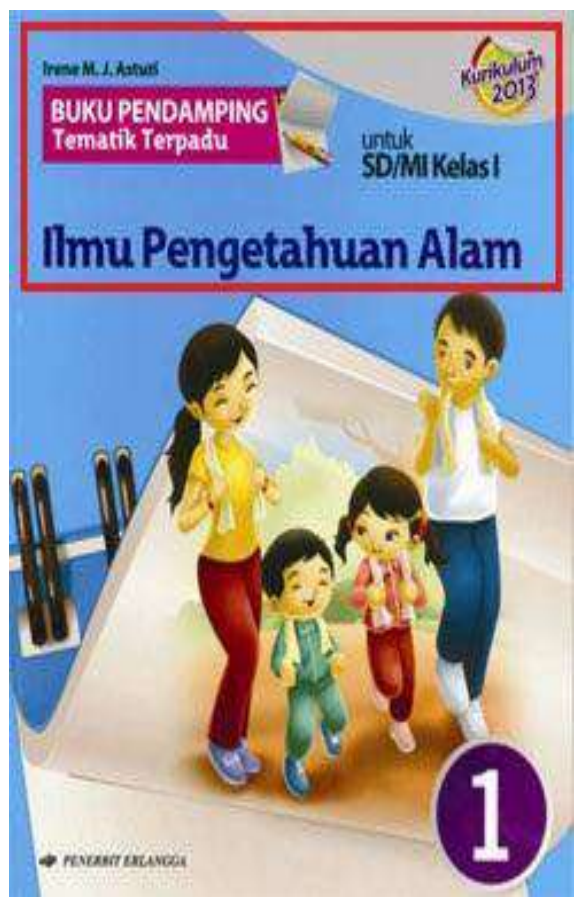

jenis buku yang menggunakan jenis font "font desain erlangga". Judul dibuat dengan ukuran yang besar biasanya ukuran 22 pt-30 pt. Tujuan dibuat besar agar terlihat jelas judul buku yang memudahkan siswa membacanya. Elemen visual pada cover memuat ilustrasi yang menggambarkan isi naskah, logo penerbit, dan angka. Angka satu yang diberi bulatan itu termasuk gaya selingkung penerbit yang menggambarkan desain isi dengan ciri khas melengkung pada beberapa elemen di dalam buku tersebut.

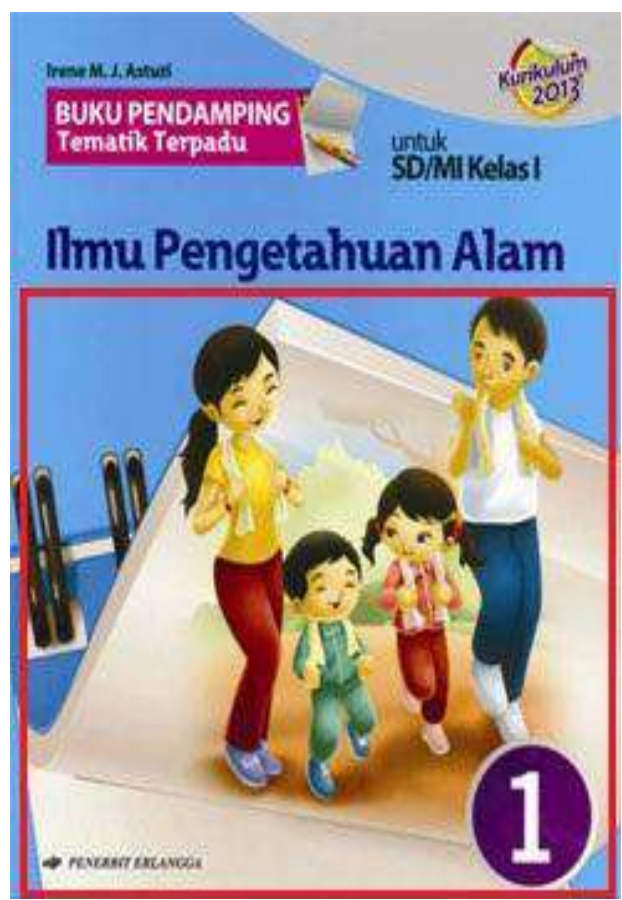

Gambar 4 Contoh Elemen Teks dan Visual pada Cover

Tata Letak Ilustrasi dari Segi Proporsional Ilustrasi Buku Pendamping Tematik Terpadu IPA Jilid 1

1. Naskah Ilmu Pengetahuan Alam (IPA)

Buku Pendamping Tematik Terpadu IPA Jilid 1 adalah buku terbitan
Erlangga dan termasuk dalam kategori buku latihan. Buku Pendamping Tematik Terpadu IPA Jilid 1 ini terdiri dari delapan tema, yaitu tema satu: diriku, tema dua: kegemaranku, tema tiga: kegiatanku, tema empat: keluargaku, tema lima: pengalamanku, tema enam: 
lingkungan bersih, sehat, dan asri, tema tujuh: benda,binatang, dan tanaman di sekitarku dan tema delapan: mengenai peristiwa alam. Tema-tema tersebut disusun berdasarkan pemetaan kompetensi dasar. Buku Pendamping Tematik Terpadu IPA Jilid 1 buku ini bermanfaat untuk mengukur pencapaian kompetensi dasar Ilmu Pengetahuan Alam dan menambah pengetahuan siswa. Selain itu, buku ini juga untuk mendukung proses pembelajaran demi mencapai keteladanan sikap, keterampilan, dan pengetahuan siswa. Buku ini disusun secara sistematis sesuai dengan kurikulum 2013.

\section{Proporsional Ilustrasi}

Pengaturan tata letak harus dilakukan pada semua jenis buku. Sebab buku yang tampilannya bagus, rapi, dan enak dilihat oleh pembaca menjadi andalan setiap penerbit. Kegiatan tata letak yang juga harus diperhatikan adalah segi proporsional ilustrasi. Pada Buku Pendamping Tematik Terpadu IPA Jilid 1, penggunaan ilustrasi ditempatkan pada sebuah box gambar. Penggunaan box gambar agar terlihat lebih rapi dan sekaligus menunjukkan salah satu ciri khas dari penerbit Erlangga. Memasukkan ilustrasi ke dalam box gambar harus proporsional. Apabila ilustrasi buku tidak proporsional maka tampilan ilustrasi akan terlihat tidak seimbang baik dalam bentuk maupun ukurannya.

\section{Software Pendukung}

Pembuatan tata letak Buku Pendamping Tematik Terpadu IPA Jilid 1 ini menggunakan software pendukung, seperti Microsoft Office Word 2007, Adobe Indesign CS5, Adobe Ilustrator CS6, dan PDF (Portable Document Format). Microsoft Word untuk mengolah elemen teks sedangkan Adobe InDesign digunakan untuk membuat rancangan/templet dan mengatur tata letak semua elemen-elemen yang terdapat dalam naskah. Sedangkan Adobe illustrator, untuk membuat atau mengedit sebuah ilustrasi demi kebutuhan naskah. Software PDF berfungsi mengeksport data yang siap cetak atau melihat hasil akhir. (1) Microsoft Office Word 2007 berfungsi untuk mengolah elemen teks. Selain mengedit secara manual, editor materi IPA di penerbit Erlangga biasanya mengedit naskah dengan menggunakan software tersebut dengan format .doc ; (2) Adobe Indesign CS5 merupakan aplikasi desain layout. Aplikasi ini berfungsi untuk me-layout sebuah halaman yang akan digunakan dalam percetakan dan penerbitan. Aplikasi ini mampu mengatur tata letak dengan jumlah halaman yang banyak dengan waktu singkat dan kenyamanan dalam membuat desain dengan multiple pages design (tata letak dalam beberapa halaman) karena adanya fungsi master pages; (3) Adobe Ilustrator CS6 merupakan program pendukung pengolah vektor (sekumpulan garis). Program ini untuk memperbaiki ilustrasi-ilustrasi 
yang masih salah atau membuat dari awal ilustrasi karena ketika melakukan pengeditan, gambar tidak akan pecah dan gambar vektor akan tetap tajam saat dicetak; (4) PDF (Portable Document Format) digunakan untuk mempresentasikan dokumen dua dimensi yang meliputi teks, huruf, dan grafik vektor dua dimensi. Program ini untuk mengeksport data yang siap cetak atau melihat hasil akhir Buku Pendamping Tematik Terpadu IPA Jilid 1.

\section{Format Penyimpanan}

Format penyimpanan file ilustrasi pada Buku Pendamping Tematik Terpadu IPA Jilid 1 ini umumnya berupa format JPEG, PNG, atau TIF tergantung dari kebutuhan ilustrasi akan diletakkan dibagian yang mana. (1) Format JPEG (Joint Photographic Expert Group) mampu menyimpan gambar dengan mode warna RGB, CMYK, dan Grayscale. Selain itu, JPEG juga mampu memberikan warna dengan kedalaman 24 Bits atau setara dengan 16 juta warna. Fomat ini terdapat pada aplikasi Adobe Photoshop. Pada format penyimpanan file ilustrasi jika ilustrasi dipakai untuk mendampingi isi/bodytext dan ukurannya tidak besar dapat menggunakan dapat menggunakan format penyimpanan JPEG (Joint Photographic Expert Group), agar kualitas ilustrasinya baik; (2) PNG (Portable berfungsi sebagai alternatif lain dari format file GIF. Kelebihan format file PNG ini dibandingkan dengan format file GIF adalah kemampuannya menyimpan file dalam bit depth hingga 24 bit serta mampu menghasilkan latar belakang (background) yang transparan dengan pinggiran yang halus. Sama halnya pada penyimpanan JPEG, format ini dapat dipakai untuk mendampingi isi/bodytext; (3) TIF (Tagged Image Format File) mampu menyimpan gambar dengan kualitas hingga 32 bit. Format file TIF merupakan format yang dipilih dan sangat disukai oleh para pengguna komputer grafis terutama yang berorientasi pada publikasi (cetak). Untuk format penyimpanan ilustrasi yang nantinya akan dipakai untuk cover depan/sampul sebuah buku, sebaiknya format penyimpanannya berupa TIF (Tagged Image Format File) karena format tersebut hasil kualitas ilustrasinya lebih tajam dan tidak pecah.

\section{Perbandingan Ilustrasi dengan Teks pada Buku Pendamping Tematik Terpadu IPA Jilid 1}

Setelah dilakukan perhitungan, perbandingan ilustrasi:teks adalah 55:45 persen. Perhitungan dilakukan dengan melihat berapa banyak ilustrasi dan berapa banyak teks pada setiap halaman. Hal ini dilakukan untuk mengetahui perbandingan antara ilustrasi dan teks pada buku tersebut. Teks dan gambar tidak terpisah karena teks soal tersebut digambarkan dengan sebuah ilustrasi yang dapat memudahkan siswa memahami soal-soal. Ilustrasi yang 
dibuat dapat berupa situasi atau objek-objek. Menurut Prof. Dr. B.P. Sitepu, M.A. dalam bukunya Penulisan Buku Teks Pelajaran (2012:133) menyatakan bahwa perbandingan ilustrasi dan teks dalam buku teks pelajaran untuk siswa SD/MI kelas 1-3 adalah 60:40 persen. Sedangkan pada Buku Pendamping Tematik Terpadu IPA Jilid 1 berbanding 55:45 persen. Dengan demikian, pada buku tersebut masih harus ditambah ilustrasinya agar memiliki keseimbangan antara banyaknya ilustrasi dan teks.

\section{Peran Ilustrasi}

Peran ilustrasi dalam sebuah buku sangat penting yaitu sebagai pendamping isi buku. Begitu juga pada Buku Pendamping Tematik Terpadu IPA Jilid 1 ini, ilustrasi yang disajikan sangat penting dan sesuai dengan isinya serta dapat mempermudah siswa untuk lebih cepat memahami maksud dari isinya. Ada teks yang tidak dapat berdiri sendiri dan harus jelas maksud dari tulisan tersebut. Oleh karena itu, agar proses pembelajaran yang diinginkan dapat tercapai maka diputuskan untuk diberi ilustrasi-ilustrasi. Beberapa syarat ilustrasi yang baik, meliputi ilustrasi yang dibuat nantinya dapat memperjelas isi atau substansi, sebagai pelengkap dari teks atau materi itu sendiri, menambah daya imajinasi anak didik, membuat susunan tata letak lebih dinamis, ilustrasi tajam tidak buram, sesuai dengan isi, dan ukuran ilustrasi proposional.

\section{Kendala Dalam Menata Letak Ilustrasi dari Segi Proporsional Ilustrasi dan Cara Mengatasinya}

Selama proses pengaturan tata letak ilustrasi dari segi proporsional ilustrasi Buku Pendamping Tematik Terpadu IPA Jilid 1 terdapat kendala, yaitu ilustrasi yang telah selesai dibuat oleh tim multimedia, harus dimasukkan dalam box gambar yang telah dibuat pada program Adobe Indesign. Namun pada saat memasukkannya, ilustrasi tersebut justru terlihat tidak proporsional.

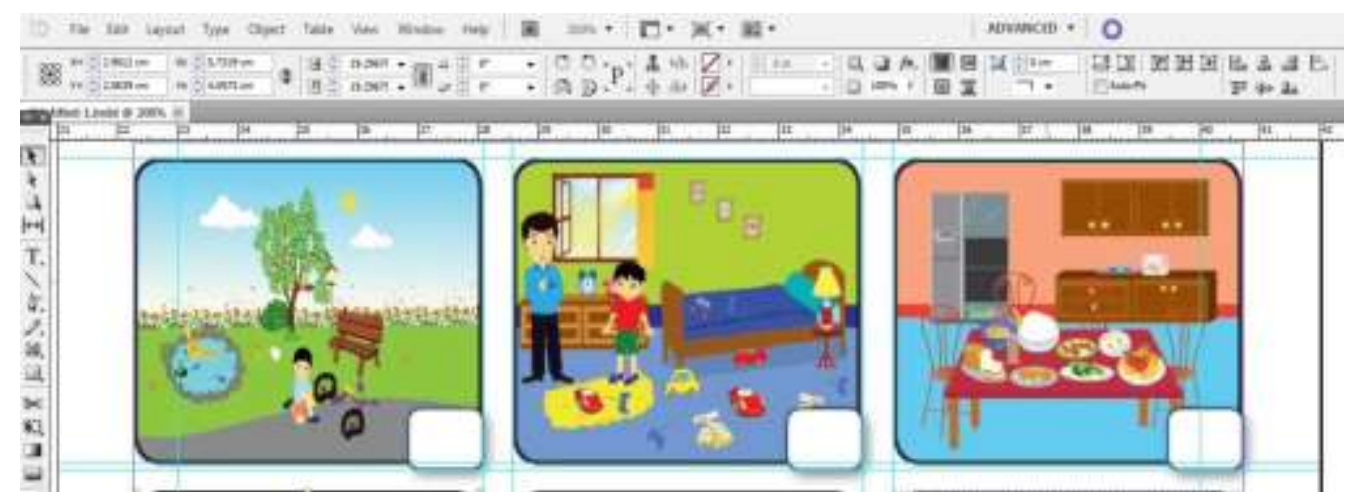

Gambar 5 Contoh Gambar yang Tidak Proporsional 
Ada dua solusi dalam memasukkan ilustrasi pada box gambar agar terlihat proporsional ilustrasinya berdasarkan observasi di penerbit Erlangga, yaitu dengan mengubah ukuran/bentuk ilustrasi dengan program Adobe Ilustrator dan mengubah ukuran/bentuk box gambar pada Adobe Indesign.

\section{Memasukkan Ilustrasi dalam Box}

Gambar pada Buku Pendamping Tematik Terpadu IPA Jilid 1

Memasukkan ilustrasi ke dalam box gambar dengan menggunakan program Adobe Indesign agar ilustrasi tersebut bentuknya proporsional tidak mudah mengaturnya, oleh karena itu penerbit Erlangga mempunyai dua solusi, yaitu:

1. Mengubah ukuran/bentuk ilustrasi dengan program Adobe Ilustrator

Solusi yang pertama dengan mengganti ukuran/bentuk ilustrasi dengan program Adobe Ilustrator. Hal ini dilakukan jika ilustrasi yang telah dimasukkan dalam box gambar tetapi ilustrasi tersebut terlihat tidak proporsional walaupun sudah diatur ukurannya agar sesuai. Sedangkan jika ilustrasi diatur secara manual dapat menyebabkan ilustrasi tersebut banyak bagian yang terpotong. Oleh karena itu, ilustrasi harus diubah ukuran atau bentuknya dengan menggunakan Adobe Ilustrator.

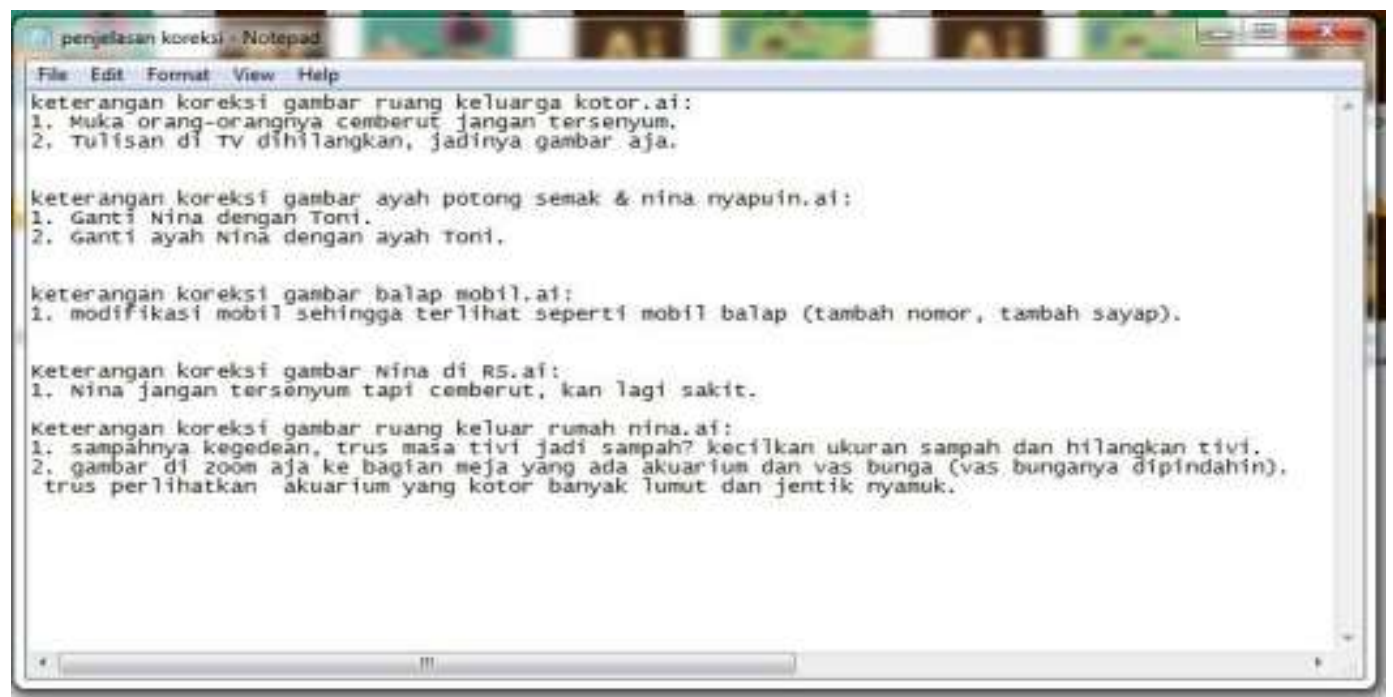

Gambar 6 Intruksi Ilustrasi yang harus diperbaiki

Ilustrasi dibuat atau diedit dengan menggunakan program Adobe Ilustrator. Ilustrasi tersebut diubah oleh ilustrator atau editor materi yang menangani naskah tersebut. Jika diubah oleh ilustrator, maka Editor yang harus memberitahukan tim multimedia bahwa ukuran atau bentuk ilustrasi tidak sesuai dengan box gambar. Editor juga harus menunjukkan box gambar yang akan dipakai untuk memasukkan ilustrasi tersebut. Hal ini bertujuan agar ilustrasi terlihat lebih proporsional 
dan seperti ukuran yang sebenarnya. Tidak hanya itu, terkadang ilustrasi yang telah dibuat harus diperbaiki kembali karena terjadi perbedaan pernyataan antara teks dan situasi ilustrasi. Editor IPA menuliskannya pada notepad bagian apa saja yang harus diperbaiki. Kegiatan tersebut juga dilakukan oleh tim multimedia dan dikerjakan pada program Adobe Ilustrator

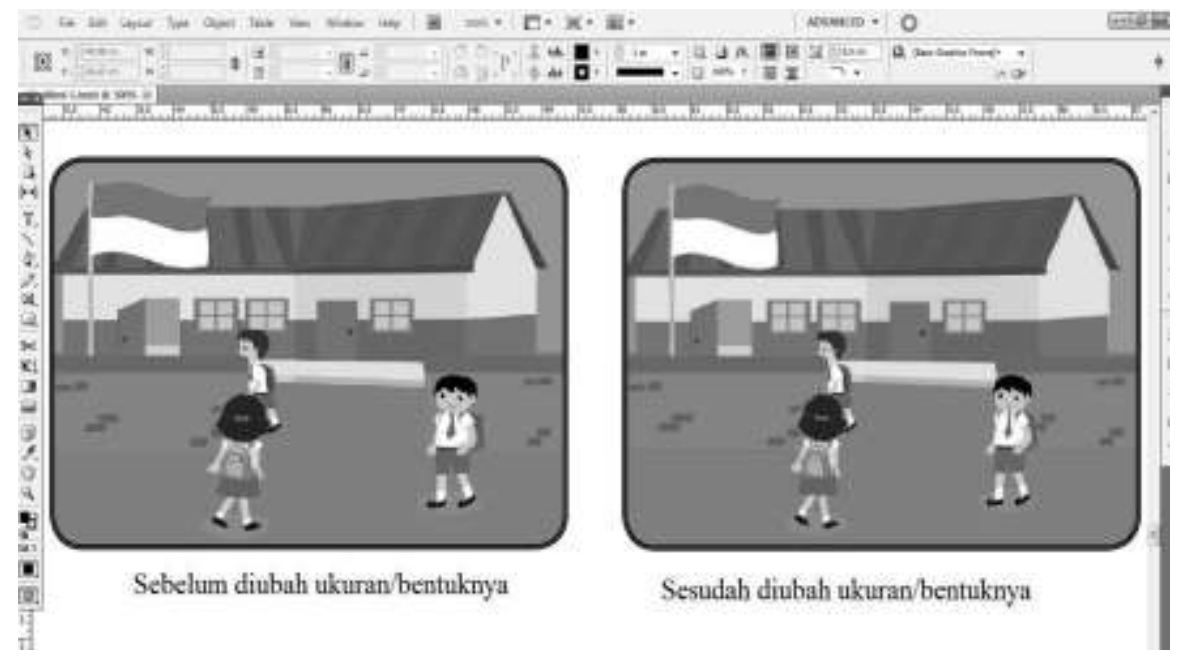

Gambar 7 Perbedaan ukuran atau bentuk ilustrasi sebelum dan sesudah diubah

2. Mengubah Ukuran atau bentuk Box Gambar pada Adobe InDesign.

Solusi kedua untuk menghindari ilustrasi yang tidak proporsional selain dengan mengubah ilustrasi, yaitu dengan mengubah ukuran atau bentuk box gambar dalam Adobe InDesign. Apabila ukuran ilustrasi yang dibuat lebih sesuai ukuran atau bentuknya daripada box gambar maka box gambar dapat diubah dengan mengikuti ukuran (bentuk) ilustrasi. Seperti contoh berikut ini :

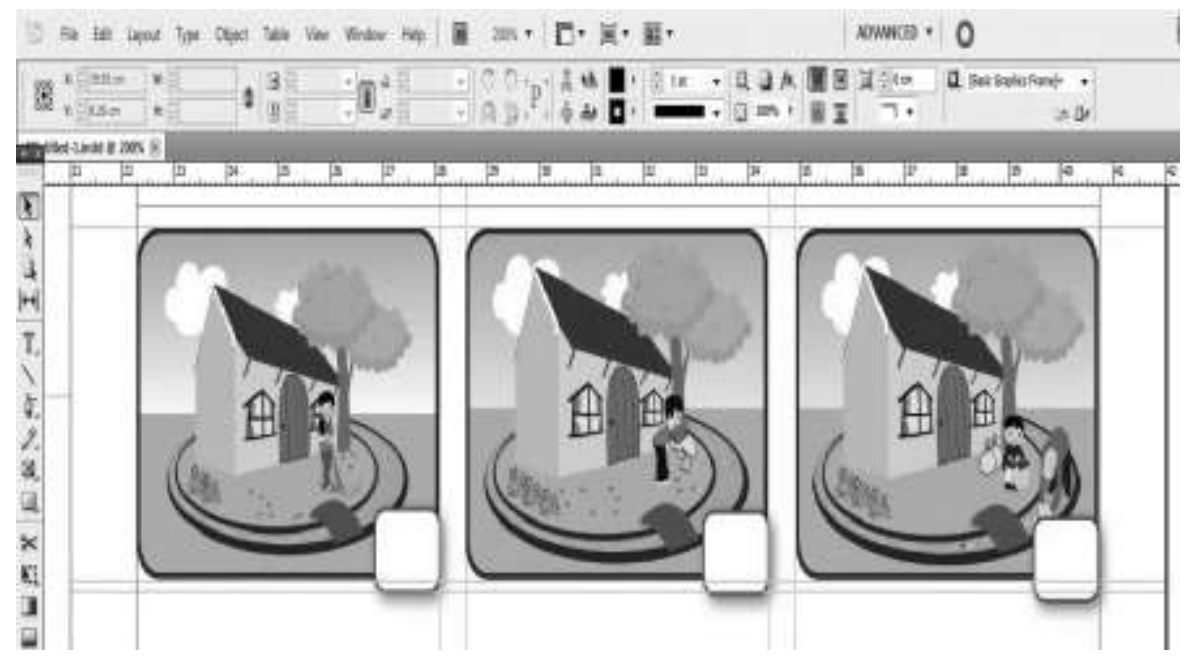

Gambar 8 Box gambar yang telah diubah ukuran atau bentuknya 


\section{PENUTUP}

Berdasarkan observasi dan studi pustaka yang dilakukan di penerbit Erlangga penulis menyimpulkan bahwa pengaturan tata letak dilakukan tidak hanya pada elemen teks namun juga dilakukan pada elemen visual. Ilustrasi termasuk dalam elemen visual yang mempunyai peran penting dalam sebuah buku, terutama jika buku tersebut digunakan untuk siswa kelas satu. Untuk hal ini harus dilakukan penataletakkan yang rapi dan menarik. Selama pembuatan tata letak khususnya tata letak ilustrasi dari segi proporsional ilustrasi pada Buku Pendamping Tematik Terpadu IPA Jilid 1, penerbit menggunakan box gambar dan pada setiap sisinya melengkung tidak lancip. Kendala utamanya adalah kesulitan memasukkan ilustrasi ke dalam box gambar secara proporsional. Cara mengatasinya ialah dengan mengubah ukuran/bentuk ilustrasi melalui program Adobe Ilustrator atau dengan merubah ukuran/bentuk box gambar pada Adobe InDesign.

Untuk mengatasi masalah yang ditemukan dalam proses pembuatan buku tematik terpadu terbitan Erlangga, bagian setting, desain,editor, dan ilustrator harus saling berkomunikasi mengenai buku tersebut yang didukung oleh adanya pengetahuan luas mengenai tata letak terkait pada elemen visual/ilustrasi. Hal ini penting agar diperoleh pemahaman yang sama mengenai isi buku sehingga dapat menggunakan ilustrasi yang tepat. Buku ini cukup baik untuk jenis buku latihan atau buku soal karena ilustrasi didalamnya sangat sesuai dengan soal-soal yang ada.

$$
\text { Buku Pendamping Tematik }
$$

Terpadu IPA Jilid 1 ini dicetak dengan warna hitam putih. Agar terlihat bagus dan menarik harus diatur keseimbangan antara elemen visual dan elemen teks. Brif atau naskah mentah yang diberikan kepada illustrator sebaiknya sudah dibuatkan box gambarnya seperti apa agar bagian tim multimedia dapat menyesuaikan bentuk dari ilustrasi yang akan dibuatnya. Selain itu, komunikasi kepada penulis juga lebih diutamakan agar buku tersebut sesuai dengan maksud penulis dan sesuai kurikulum yang dikeluarkan.

\section{DAFTAR RUJUKAN}

Kusrianto. Adi. 2007. Pengantar Desain Komunikasi Visual. Yogyakarta: Penerbit Andi.

Rustan. Surianto. 2010. Layout Dasar dan Perapannya Edisi 2009. Jakarta: Gramedia Pustaka Utama.

Proyek Pendidikan dan Pembinaan Tenaga Teknis Grafika. 1979.

Tata Letak dan Perwajahan. Jakarta: Pusat Grafika Indonesia.

Ambrose Gavin dan Harris Paul. 2011. The Fundamentals of Creative Design. AVA Academia.

Departemen Pendidikan Nasional. 2008. Kamus Besar Bahasa Indonesia Edisi Keempat. 
Jurnal Publipreneur, Vol. 2, Nomor 3, Juni 2014, ISSN: 2338-5049

Jakarta: Gramedia Pustaka

Utama.

Eneste. Pamusuk. 2009. Buku Pintar

Penyuntingan NASKAH EDISI

KEDUA. Jakarta: Gramedia

Pustaka Utama.
Sitepu. 2012. Penulisan Buku Teks

Pelajaran. Bandung: PT

Remaja Rosdakarya.

Kuncoro Mudrajad. 2009. Mahir

Menulis. Jakarta: Penerbit Erlangga. 